\title{
Two Views of the Effects of Government Budget Deficits in the 1980s
}

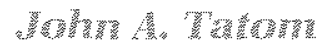

EDERAL budget deficits in the United States have become a major concern since they rose to nearly $\$ 200$ billion in fiscal 1983. In the absence of new policy efforts, the deficit is projected to continue at $\$ 200$ to $\$ 250$ billion per year for the rest of this decade.

Deficits, according to most popular analyses, raise aggregate demand for goods, services and credit, which boosts output, employment, prices and interest rates and reduces private investment."

This article examines the empirical and theoretica basis of this mainstream view. It also presents an alternative set of hypotheses, which indicates that fiscal policy actions are largely and directly offset by private spending changes, rendering the aggregate demand and interest rate channels of influence insignificant.

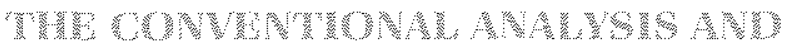

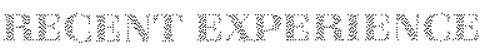

Conventional wisdom holds that recent and prospective U.S. budget deficits have significantly raised

John A. Tatom is an assistant vice president at the Federat Reserve Bank of St. Louis. Michael L. Durbin provided research assistance. An earlier version of this paper was presented at the Spring Conference of the Financial Research Foundation of Canada on April 16, 1985, in Ontario, Canada.

Most introductory lextbooks emphasize the boost to aggregate demand, interesł rates and prices arising from "expansionary" fiscal policy actions. See, for example, the macroeconomics sections of Dolan (1983), McConnell (1984), or Samuelson and Nordhaus (1985). These texis also discuss some of the theoretical reservalions about these channels of influence raised below. Note that the hypothesized reduction in investment does not exceed the intial rise in aggregate demand for goods and services that arises from deficitincreasing fiscal actions. interest rates and have promoted the crowding out of investment. But this view is based on the conventional deficilaggregate-demand hypothesis that also holds that an expanded deficit should increase both output and the price level. The latter conclusions became center stage in 1980-81 when the Reagan economic program was debated. Their empirical validity, which remains largely unquestioned, was strongly rejected after mid-1981 when, with the deficit expanding, inflation plummeted from double-digit levels and the economy entered the longest and most severe recession since the 1930 s.

Interest rate developments were also at odds with the conventional view. Chart 1 shows the total govenment deficit as a percent of GNP and the AAA bond yield since 1950. The surge to historically high interest rates occured well before the 1981-82 surge in the deficit." The recent rise in the deficit occurs from the third quarter of 1981 to the fourth quarter of 1982 , when the AAA bond yield declined from about 15 percent to 12 percent. Then, in $1983-84$, the deficit declined sharply relative to GNP, but the $A A A$ bond vield rose.

The principal diffouly in finding a positive relationship between deficits and interest rates arises from the fact that both the budget deficit and interest rates move cyelically and in opposite directions. Hence, it is not surprising, especially for shortermanterest rates, that empirical studies often tum up supposedly sig-

\footnotetext{
Similarly, the appreciation of the dollar precedes the deficit surge. The steady upward appreciation of the trade-weighted exchange rate for the U.S. dollar began at the end of 1979 (when interest rates soared) and was not noticeably affected by the 1981-82 deficit surge.
} 
thors :

Aaa Bond Yield and Total Government Deficit as a Percent of GNP

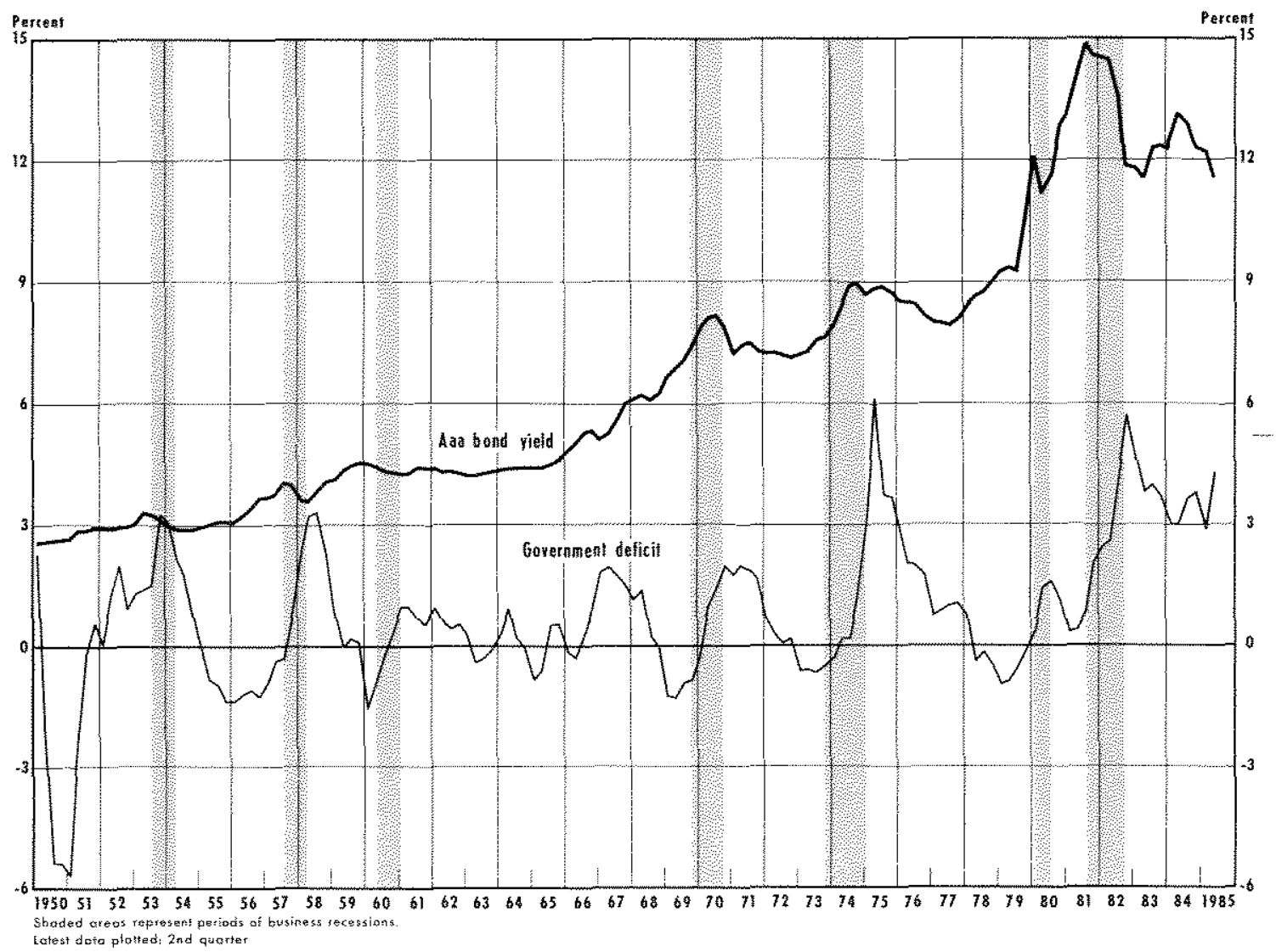

nificant negative statistical relationships between interest rates and deficits. When one uses dehcits constructed on a high-employment basis - that is, with systematic cyclical intuences removed - qhere still is no evidence of a posive rebationship beween deficits and either short or long-tem interest rates over the period $1955-83 .^{\text {. }}$

'See Talom (1984). Efiorts to contro for huture inflation expectations to capture real interest rate changes do not affect the observed absence of a deficit effect on interest rates. Also, some andysts conjeclure that the debtGMP ratio positively influencas the inferest rate. Regressions of quarterly changes in the AAA bond yield or three-month Treasury bit rates on changes in the ratio of net federal debt to GNP, controling for changes in the capacity utilization rate and the intation rate one quarter ahead, yield a negative but insignificant relationship for the debt ratio over the period $/ 1955$ to III 1984.

The independence of interest rates from the deficit has been observed by Evans (1985). Also see Feldsten and Eckstein (1970), Sargent (1973), and the recent Treasury study (1984). Plosser (1982) delais many of the theoretical and econometric difficuties of previous tests of the interest rate/deficit hypothesis.

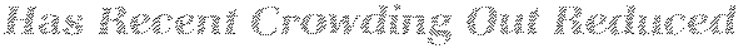

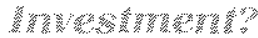

Chav 2 shows private domesto invesment as a shame of CNP. Investment has deched and risen cychcally since 1980 , but these swings obscure the strength of investment over the past forr years. When the capaciry uthization rate is relatively low, the demand for new capital can be met mone eastry by the remoloymont of existing caplat instead of investment in new hachties. Thus, the share of investment in GNP and whe capacty utilizan rate tend to move in randem or to be positively condated. In 1984, the capacity utilization rate was well below its 1979 level, when the prion peak investment ratio was acheved. Nevertheless, the shane of private domestic investment in? CNin in 1984 virtually matched this peak level.

Even plant and equipment honesidental fxed invesment has ben quite high by historical standm ards, despite tho recessions in 1980-82. Wher nominal 
Chast 2

Nonresidential Fixed investment as a Percent of GNP

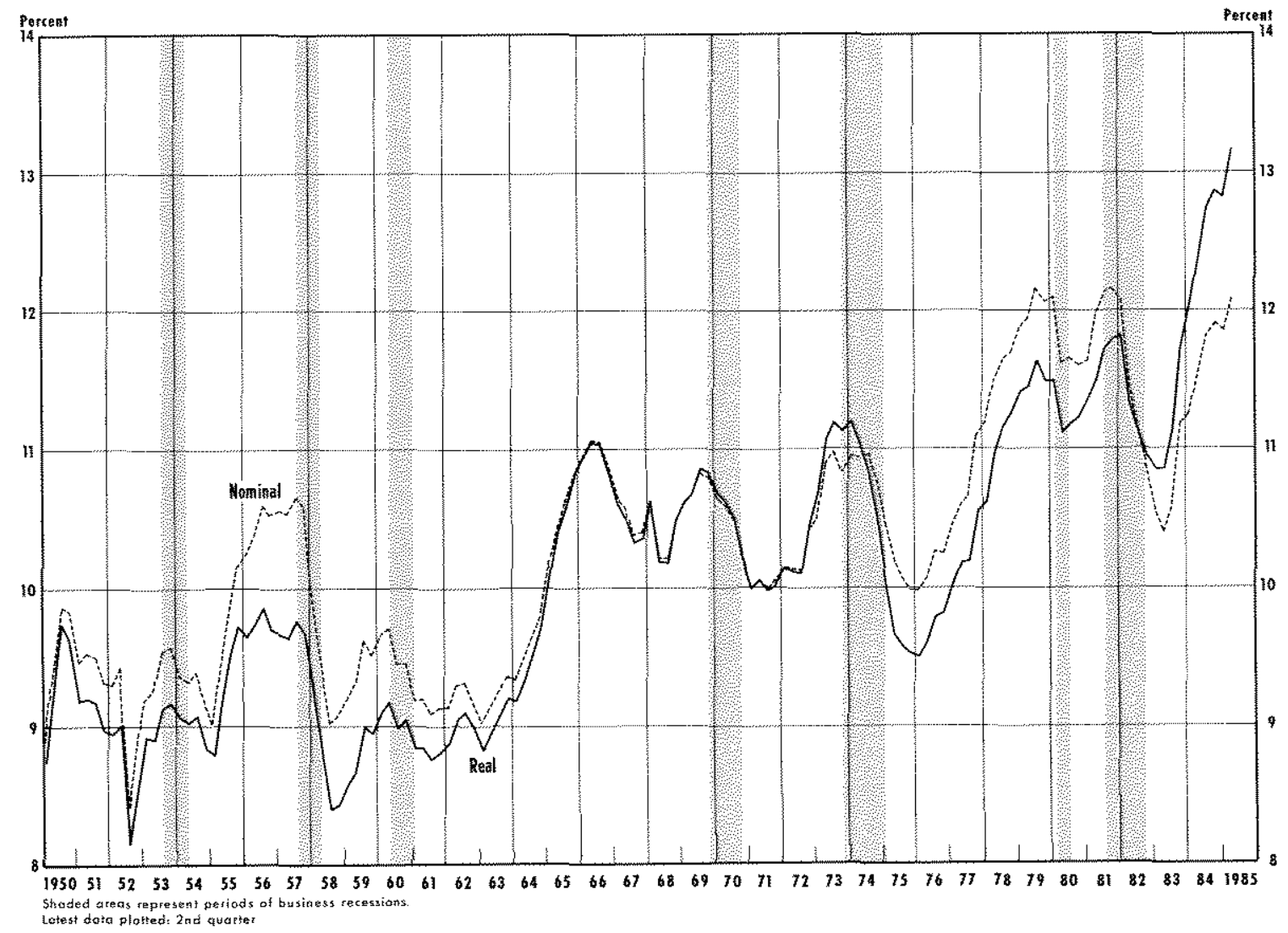

nonresidential fixed investment and GNP are adjusted by their respective deflators, in order to measure real investment as a share of real GNP, the recent strength of plant and equipment spending relative to real GNP represents a postwar peak performance. This share is shown in chart 3 . Note that, even at the depths of the previous two recessions, real plant and equipment purchases were about as large a share of real GNP as the 11 percent attained at the peaks of previous investment booms in 1965 and 1969. "The conventional argu" ment, that investment has been unusualy weak due to the higher real rates of interest, is not obviously imporlant in cxplaming recent invesment experience.

The reason for the greater real sirength is that the relative price for new plant and equipment declined sharply since 1980 . The nonresidential fixed investment deflator declined 14.2 percent relative to the GNP deflator from 1980 to 1984.

\section{"蒙要}

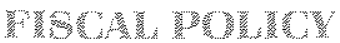

$A$ closer look at the theoretical mechanism underlying conventional analvses of the deficit reveals some of the potential shortcomings of these analyses. In the textbook view of the effects of fiscal policy on the economy, increased govermment deficits expand aggregate demand, spending, output and employment, regardless of whether larger deficits arise from increases in purchases, Iransfer payments or reductions in taxes. So-called balanced-budget increases in transfer payments, in which a rise in transfer payments is matched by a rise in taxes, leave aggregate demand unchanged (ignoring distribution effects), while taxfinanced increases in govemment purchases raise aggregate demand.

Such comentional analyses also take into accoun crowding out - reductions in private spending that 
Chises 3

Private Domestic Investment as a Percent of GNP

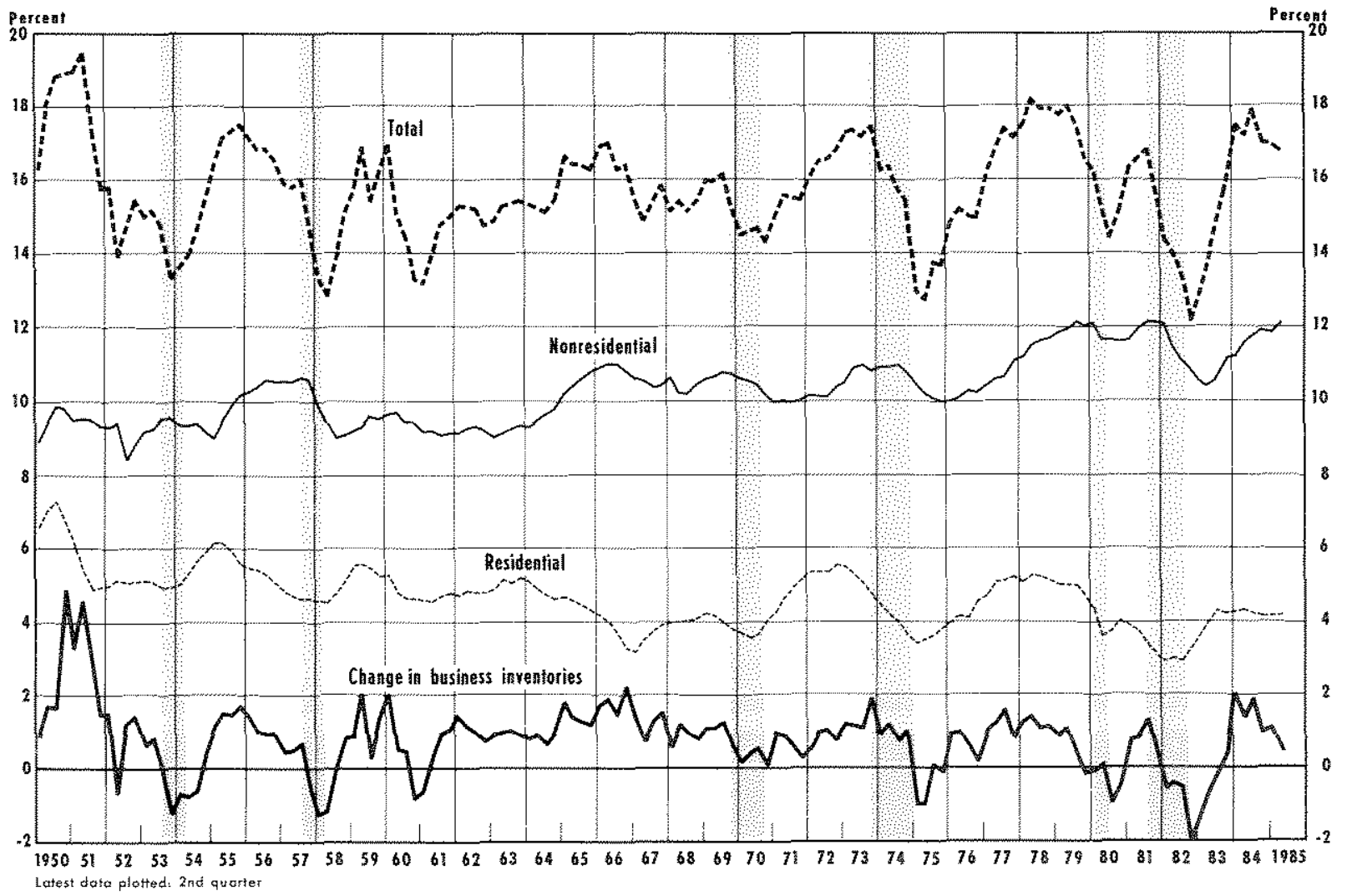

occur due to fiscal policy changes. Increases in the deficit, so the argument goes, result in increased competivion in credit markets, thus bidding up interest rates. Also, if fiscal policy actions raise aggregate demand, the increased competition in the market for goods and services bids up the general level of prices. For both reasons, real private spending is reduced, or crowded out. Households reduce their current real consumption expenditures and increase saving: firms reduce roal investment spending in response to a higher interest rate.

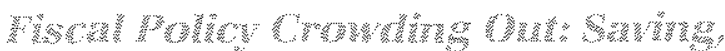

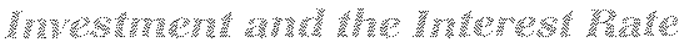

The important link between fiscal policy, aggregate demand and interest rates and the concept of crowding out of private expenditures can be illustrated in the market for saving. In figure 1 , the demand for saving is taken to be the demand for funds to finance investment. Other things that influence investment remaining the same, the demand for invesment or for saving to finance it, is inversely related to the interest rate. The supply of saving consists of private saving household disposable income less desired consumption expenditukes - and govemment saving - the excess of tax receipts over govemment expenditures, or the budget surplus. In figure 1, the national saving scluedule is drawn as upward-sloping, indicating that, given income, households reduce consumption expenditures and save more at higher interest rates. In equilibrium at point $A$, the interest rate equates the supply and demand for national saving at interest rate $i_{i,}$

In the conventional analysis, fiscal policy actions affect national saving, investment and the interest rate by (1) directly changing the budget supplus or government saving, and/or (2) altering private saving, such changes shift the national saving schedule. Given GNP 


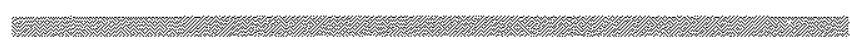

Figure 1

Hational Saving, Investment and the Rate of Interest

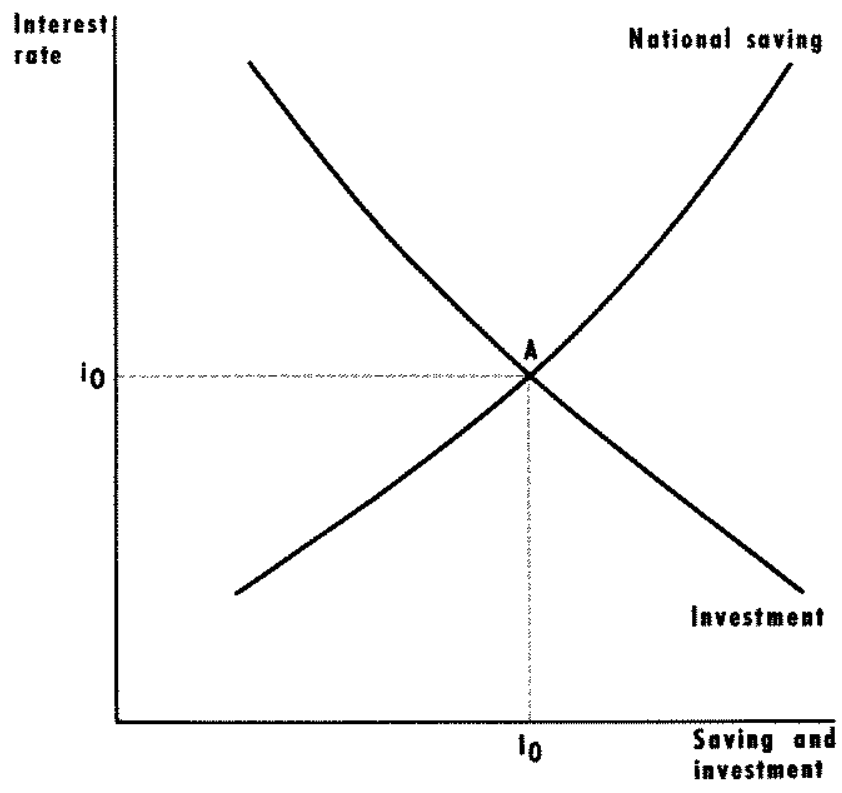

and interest rates, a fall in taxes or a rise in transfer payments (financed by borrowing) adds to disposable income, increasing both private consumption expenditures and private saving. Since part of the tax cut or transfer payment is spent for consumption, the rise in private saving is less than the deficit increase. Thus, national saving declines.

Such a decline also indicates that desired aggregate demand for goods and services has risen so that it must exceed the given level of GNP; the aggregate demand increase equals the reduction in national saving. With no change in GNP, the interest rate must rise to equate national saving and investment. In response to the higher interest rate, investment is crowded out, or declines, but some of the initial shortfall in national saving is eliminated since individuals also increase private saving.

A rise in government purchases also affects national saving. In contrast to a tax cut or a rise in transfer payments, a rise in government purchases does not change disposable income, so consumption expenditures and private saving remain unchanged. But the rise in purchases raises the budget deficit or reduces government saving, National saving falls by exactly the change in aggregate demand for goods and services, as was the case above for the tax or transfer payment change. In this case, however, the rise in aggregate demand is the government's, while before it was the policy-induced change in private consumption expenditures As before, however, interest rates will tend to rise, increasing private saving and reducing consumption and investment expenditures.

Tax-financed changes in government purchases, on the other hand, reduce private saving, given the interest rate and GNP. The higher tax reduces disposable income and therefore both consumption expenditures and private saving. The reduction in private saving is less than the tax increase, because private expenditures on goods and services also decline. Since the government deficit does not change with such a fiscal action, the decline in national saving equals the reduction in private saving. The reduction in national or private saving again indicates a rise in aggregate demand for goods and services. Taxfinanced changes in transfer payments have no effect on aggregate demand for goods and services or the national saving schedule in figure 1 , since the government deficit and disposable income remain unchanged. Thus, private and total spending on goods and services and private and national saving are unaffected.

In summary, the initial effects of fiscal policy actions on private and national saving are the critical counterparts of any initial change in aggregate demand for goods and services; both indicate the extent of upward pressure on interest rates. The analysis here illustrates the importance of both of these initial shifts. It also indicates why crowding out tends to occur. In the conventional analysis, however, crowding out is generally presumed not to be complete?

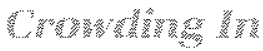

The growth in aggregate demand associated with reductions in national saving can raise or "crowd in" GNP. When GNP rises, disposable income, consumption expenditures and private saving rise; the initial reduction of private and national saving is offset by

\footnotetext{
5The Council of Economic Advisers (1985), pp. 70-77, suggests that economic theory and evidence support "complete" crowding out, where the total real demand for goods and services is unaffected by fiscal policy actions. Whether this crowding out, primarily of investment, arises through interest-rate or price-level crowding out or direct substitution of public for private expenditures is not indicated.

The Congressional Budget Office (1985) also provides a detailed discussion of the effects of deficits. A recent review by Brunner (4984) provides the best recent discussion of the theoretical issues associated with the macroeconomic theory of fiscal policy. Also, see Carlson and Spencer (1975).
} 
increases in both as GNP increases. The full adjust. ment of GNP, however, with interest rates constant cannot raise national saving back to its initial level, so the interest rate increase and crowding out will still occur. Note, however, that GNP cannot increase, just as interest rates cannot rise, unless the initial reduc tions in national saving occur.

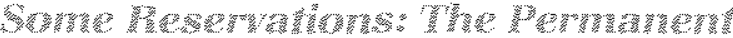 S

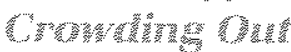

An alternative set of hypotheses about the effects of fiscal policy actions on the economy, sometimes called classical or Ricardian, emphasizes two theoreti" cal considerations called the permanent income hypothesis and ex ante crowding out. According to this view, consumption expenditures are a function of permanent income; consequently, variations in saving land saving relative to GNP/ have a large cyclical component. ${ }^{6}$ The permanent income hypothesis also enlails a government budget constraint, which indicates that the present value of current and future government expenditures must equal the present value of current and future taxes. This constraint implies that the method of financing government expenditures is irrelevant; that is, whether current expenditures are financed through taxation or borrowing /future taxes with an equivalent present value) has no influence on the economy. Thus, changes in taxes are offset by equal changes in private saving, and national saving is unaffected.

The second consideration is that government expenditures are, to some degree, substitutes for private expenditures." For example, an increase in government expenditures for school lunches may reduce private consumption expenditures on such goods; increased public expenditures for transportation ser-

\begin{abstract}
'Textbook analyses typically distinguish between permanent and temporary changes in fiscal actions, based on the permanent income hypothesis. Temporary changes in taxes or transfer payments are generally regarded to have little effect on private spending or national saving since such changes do not alter perceptions of permanent income or wealth. A type of temporary, or at least transitory, change in the budget arises from the "cyclical deficit." When unemployment rises due to a cyclical fall in income, tax receipts decine and federal expenditures, especially transfer payments for unemployment insurance, rise. As a result, the budget deficit rises.

This consideration has come to be called the Ricardian Equivalence Theorem. It is developed by Barro $(1974,1979)$ and has received strong support from Plosser (1982), Aschauer (1985), Tanner (1979) and Kormendi (1983). See also Kochin (1974).
\end{abstract}

Bailey (1971) discusses at length the theoretical possibilities that fiscal actions directly influence private sector behavior. vices may reduce private demand for such investment goods; increased transfer payments provide assistance that may substitute for private saving and investment. To the extent that such substitution occurs, growth in government purchases crowds out private purchases with no net effect on economic activity; such growth in government purchases results in offsetting reductions in private expenditures including investment. Similarly, growth in transfer payments can affect the mix of desired private spending. No excess demand for national saving occurs, nor is aggregate demand for goods and services altered; thus, GNP and interest rates are not affected by fiscal policy.

The emphasis in this view of fiscal policy is on ex ante crowding out, in which fiscal policy actions are largely offset by direct private sector responses." An increase in government purchases does not have to affect the interest rate; either national saving could remain unaffected by government purchases, as these substitute for private consumption, or investment demand could be reduced equally, as government purchases substitute for investment purchases. Similarly, national saving and private investment can be reduced due to increased fransfer payments. Thus, aggregate demand, interest rates and the price level may not be affected by fiscal actions."

If ex ante crowding out leads to private expenditure changes that fully offset fiscal policy actions, then the effects of fiscal actions on the private and national saving will not be the same as in the conventional analysis, One fundamental difference is that a rise in taxes will reduce private saving by an equal amount. Thus, a tax hike will result in an equal reduction in private saving, leaving national saving unchanged." This implies that the effects of government expenditures on national saving are the same whether they are tax-or bond-financed.

Another major difference is that a rise in govern.

There are exceptions to the conclusion that fiscal actions do not affect aggregate demand. See Hall (1980) and Barro (1981) for discussions of the real output effects of temporary increases in government purchases, especially defense expenditures, even in a Ricardian worid.

rothe absence of effects of fiscal actions on GNP has been a feature of reduced-form estimates like the St. Lous equation for some time. See Hafer (1982) and the references there for recent analyses. Permanent adverse effects of government expenditures on investment are found in Carlson (1982). Also see the references in footnote 1 .

1in the conventional view, a rise in taxes initially reduces disposable income by an equal amount and results in a fractional reduction in private saving. The fraction, called the marginal propensity to save, is generally regarded to be relatively small, on the order of 20 to 30 percent. 


\begin{tabular}{|c|c|c|c|}
\hline \multicolumn{4}{|c|}{ 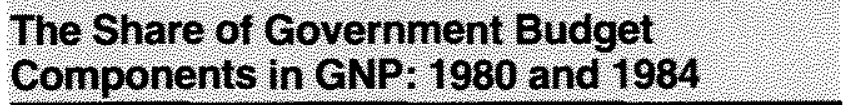 } \\
\hline & 1980 & 1984 & Change \\
\hline Tolal goverinent expenoilues & $330 \%$ & $343 \%$ & $1.3 \%$ \\
\hline Purchases of goods and sevices & 204 & 20.4 & 00 \\
\hline Transfer payments & 126 & 139 & 13. \\
\hline Total goveriment recepts & 318 & 31.0 & 088 \\
\hline Total government supolus. & $-1 / 2$ & -3.4 & 122 \\
\hline
\end{tabular}

ment purchases will reduce private consumption or raise saving, if such purchases are a substitute for private consumption expenditures. Similarly, a rise in transfer payments will reduce private saving and investment, if such payments are substitutes for saving. This can occur independently of distribution effects that in either view can yield a reduction in private saving. Finally, in the classical view, the effects of government expenditures on national saving can be associated with equal shifts in investment demand that reflect the extent to which government expenditures and investment are substitutes.":

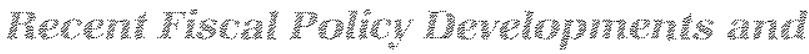 Saring}

A comparison of the implications of the two views above can be facilitated by a look at the experience in the 1980s. Table 1 shows the principal components of the total government surplus as a share of GNP in 1980, before the ballooning of the federal deficit, and 1984, the latest year available. From 1980 to 1984 , the deficit widened from 1.2 percent to 3.4 percent of GNP. The share of government purchases was unchanged, while the share of transfer payments rose. The rise in the deficit was accounted for primarily by a rise in transfer payments and, to a smaller extent, by a decline in taxes. ${ }^{13}$ These changes are explained to only a small

\footnotetext{
${ }^{12}$ Several recent studies have examined the effects of fiscal actions on personal consumption expenditures in tests of ex ante crowding out. See Aschauer (1985). Feldstein (1982) and Kormendi (1983). These tests allow for direct substitution of government purchases for private consumption expenditures and transfer payments for private saving: they do not address the extent to which government expenditures directly affect private investment expenditures.

${ }^{13}$ The decline in the share of government receipts in GNP matches the decline in the share of corporate profit tax liability in GNP.
}

extent by relative differences in the cyclical performance of the economy in 1980 and 1984 . The average unemployment rate of 7.5 percent of the civilian labor force in $\mathbf{1 9 8 4}$ was only slightly higher than the 7.1 percent in 1980. When unemployment is higher, government transfer payments tespecially unemployment compensation/ are higher, and, due to cyclical losses in income, tax payments are lower than they would be otherwise.

In the conventional analysis, the effect of the changes in the fiscal stance of the government sector shown in table 1 on saving is to raise the private saving rate (PSR) by a fraction - on the order of about 25 percent - of the increased deficit (2.2 percent) or roughly 0.5 to 0.6 percentage points. Since the expected rise in the PSR is smaller than the rise in the deficit, the national saving rate (NSR) would be expected to fall by the difference, about 1.6 to 1.7 percentage points. Associated with this shift in the national saving rate is an increase in the share of GNP allocated for consumption expenditures and an excess demand for funds to finance investment. In the conventional view, aggregate demand should have risen, improving the cyclical performance of the economy and raising prices, and interest rates should have risen; the latter, of course, should have lowered investment.

In the classical view, part of the increased deficit arose from the reduction in receipts as a share of GNP; this part is expected to be largely offset by a rise in the PSR, leaving the national saving rate unchanged. The remainder of the rise in the deficit, the rise in the share of transfer payments, would be expected to reduce private saving and investment to the extent that households view transfer payments as substitutes for such avenues of wealth accumulation. Thus, the PSR and NSR could be expected to decline by some fraction of the 1.3 percentage-point rise in transfer payments. As a net result of these two forces, the PSR should rise by up to 0.8 percentage points, and the NSR should decline slightly. Interest rates and the cyclical components of real GNP and employment should be unchanged.

Comparing 1984 with 1980, two central differences in expectations emerge between the conventional and classical views. These differences concern interest rates and the cyclical performance of the economy. The cyclical performance of the economy was slightly worse in 1984 than in 1980 . Interest rates were generally higher in 1984 than in 1980, despite a decline in inflation. For example, in 1980, the consumer price index rose 13.5 percent, while rising only 4.3 percent 
Chart $A$

Government Surplus, National Saving and Private Saving as a Percent of GNP

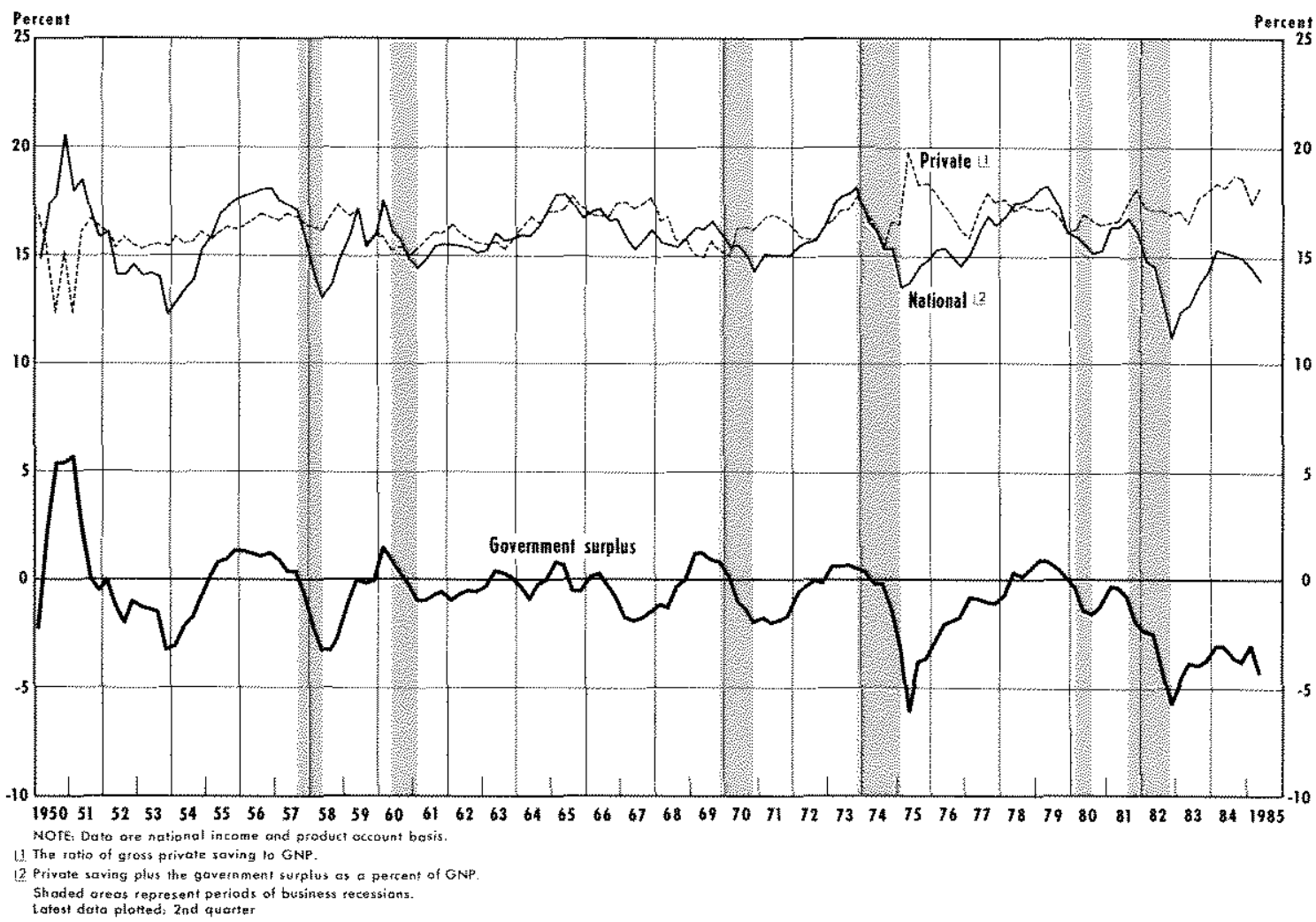

in 1984. The average Aaa bond yield, however, averaged 11.94 percent in 1980 , while averaging 12.71 perm cent in 1984. Thus, cyclical developments are more consistent with the classical view, but interest rate developments, considering these two years, are more consistent with the conventional wisdom. ${ }^{1 .}$

Of course, other factors that influence interest rates and cyclical performance are not likely to have remained the same, and more careful control for these factors is necessary to discriminate between the hypotheses. Some insight into the importance of these other factors can be gained by examining the other implications of these hypotheses.

\footnotetext{
${ }^{14}$ In fact, interest rate movements have not followed the deficit over the whole period, only in the two years indicated. This apparent contradiction arises from the fact that most of the increase in the deficit occurred in 1982 when interest rates had been declining and continued to decline, while the rise in interest rates over this period occurred in 1980 and 1981, and the decline in inflation occurred in 1981.
}

While the implications of fiscal developments in these two years for the saving rates are similar in the two views, it is useful to examine what happened to these rates. Chart 4 shows the private saving rate. government surplus share and national saving rate from 1950 to the end of 1984. The PSR has been fairly constant compared with the NSR. For example, from I/ 1950 to IV/1984, the PSR averaged 16.5 percent, exhibited no trend and had a standard deviation of only 1.02 percentage points." Such behavior, however, may

\footnotetext{
In the national income and product accounts, private saving in. cludes both personal and business saving. Private saving plus government saving equals national saving. Government saving is the budget surplus of the federal, state and focal governments. Gross private domestic investment equals national saving plus net foreign saving.

${ }^{16}$ This near constancy has been formulated as "Denison's Law" which indicates that private saving is proportional to high-employment or trend GNP but is cyclical, rising in expansions and declining during recessions. Denison's Law is developed in Denison (1958). Hickman (1966) and David and Scadding (1974). The latter indicate that Denison's Law provides strong support for Friedman's (1957) permanent-income theory of consumption.
} 


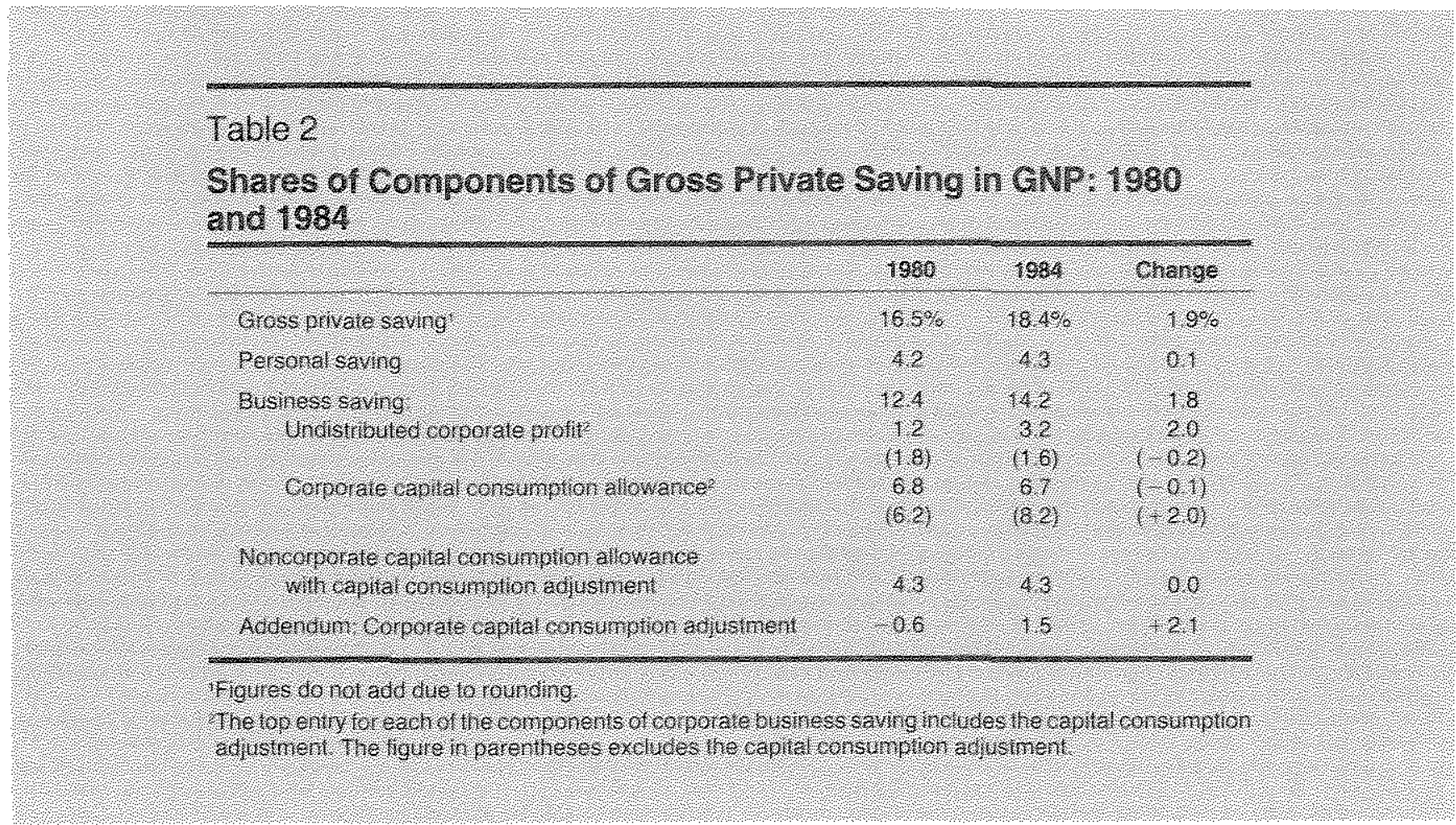

obscure the conflicing frects of varous infuences on the $\mathrm{pgR}$

The NSR appears to be strongly cychich dechning sharply in recessions. This patern must arise from cycical movenents in govermment saving since the PSR does not appear to be cylical. Gyclical dierences may not have exerted a stong intuence in companang 1984 lo 1980 performaned, however.

From 1980 to 1984, the PSR rose sharply lom an average of 16.5 percent to 18.4 percent. Based on the conventional analysis, this rise is shamply higher than that expected. Simiarly, the national saving me foll from 15.4 percent to 15.0 percent, muct smaler than the deche expected from the conventional analysis. but it may as bo be smalie than that expected from the chessical view.

The counterpart of strong saving, domestic investment, has been even stronger since 1981. In the national income and product accounts, gross saving equals gross mvestment, except for a minor shatistical discrepancy. Gross privale domestic invesment as a share of GNiprose 2.1 percentage points to 17.4 percent in 1984 , despite the 0.4 percentage-pont fall in the national saving rate. This difference is accounted for by the intow of net foreign saving, the larges share of which was due to domestic fims channelng then own funds from investment aboad ino domestic invesments. In 1980 , U.S, assets abroad rose $\$ 96.3$ billon, but this pace of nvestment plummeted to $\$ 20.9$ billon in 1984 . The pace of fow Unied Sates increased slighly over the period. Foreign assets in the united Stanes rose $\$ 98.8$ bilion in 1984, up stintly fon the $\$ 84.7$ billon pace in 1980. As a result, net toreign invesment fell from an $\$ 11.6$ billion outlow in 1980 to a net inlow of 577.9 billion in 3984

The regent behavior of invesment suggests a strong candidate for the significant omited factor accounting lor the stength of domestio saving and the rise in interest rates. This factor, the invesment incentives in the 198 tax act accounts for the relative strength of invesment, despite the higher level of interest rates in 1984 than in 1980 . More direct evidence of these effects can be seen in the dominam component of saving in the United States, business saving.

Table 2 provides a summary of components of private saving in 1980 and 1984 . The rise in the private savigg rate was vitualv all due to an increase in the business saving late The kater in turn, arose almost completely because of an increase in the compore capital comsumpion adjustment as a share of GNe. "This figure comecrs repored profits and capital con" sumplion depreciation allowances for the understatement on overstatenent of true economic depreciation, inchung losses from the use of historical rather 


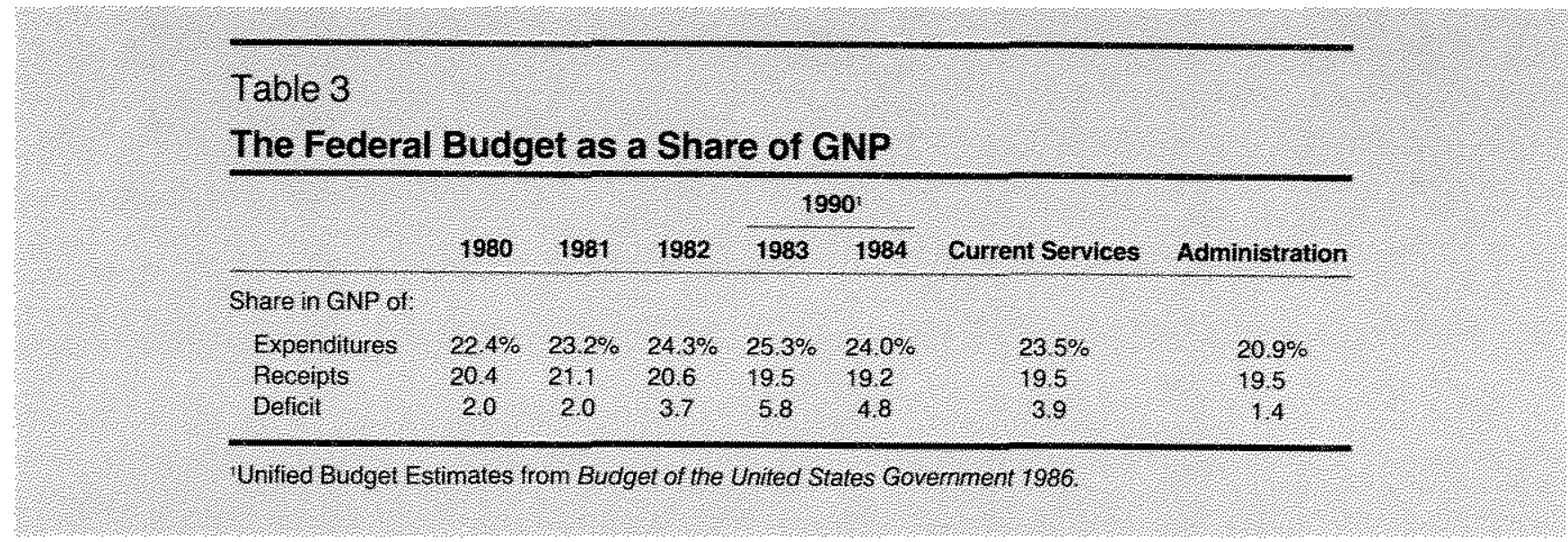

than replacement cost in computing depreciation allowances. The sharp change in this adjustment reflects the slowdown in inflation from 1980 to 1984, reducing the extent of underdepreciation due to historical cost accounting; more important, the change in the adjustment reflects the acceleration of depreciation allowed by the 1981 tax act. The latter is indicated by the large jump in the size of the corporate capital consumption allowance (without capital consumption adjustment relative to GNP. This jump accounts for the reported rise in the share of undistributed corporate profits (with adjustment) despite the lack of improvement in the cyclical performance of the economy.

Thus, other things have not been equal in the determination of saving and investment. Tax cuts arising from accelerated depreciation have added substantially to the private saving rate and made possible the cash flow to finance the deficit induced by such a loss in government revenue, without interest rate changes. But the new incentives also induced a substantial rise in the share of investment in GNP, especially in the share of plant and equipment investment and a redirection of investment by U.S. firms from abroad. Not surprisingly then, yields on most private assets rose sharply from 1980 to 1984.

The changes in saving and investment rates from 1980 to 1984 conform more closely to the expectations of the classical view than to those of the conventional analysis, especially when the investment incentives of the 1981 tax act are taken into account. In the absence of more detailed statistical analysis, however, the data do not yield decisive evidence supporting either view to the exclusion of the other. The strength of invest" ment - arising from improved incentives, despite nearly unchanged cyclical performance of the economy and a sharply higher real rate of interest - has been associated with a substantially smaller decline in the national saving rate and a much larger rise in the private saving rate than that suggested by the conventional view, however.

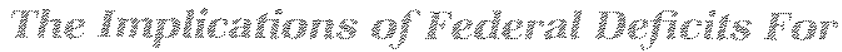

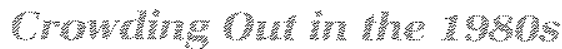

Table 3 shows the growth in federal expenditures as a share of GNP from 1980 to 1984 and unified budget estimates for 1990 . The latter are constructed assuming either no further policy changes or the implementation of administration proposals. In the absence of policy changes, expenditures are higher in each year than in 1980, resulting in an implicit crowding out of investment. "While expenditures and deficits peak as a share of GNP in 1983, the declines to 1990 are small."

The ex ante crowding-out view suggests that tax changes have no effect on national saving, but that changes in government expenditures reduce investment to the extent that such expenditures lower national saving." Increases in government expenditures

\footnotetext{
${ }^{17}$ The Congressional Budget Office (1985) discusses the effect of such deficits on the ratio of federal debt to GNP, including the view that it is the level of the debt relative to GNP rather than the deficit that affects interest rates. Their current services estimate of this ratio rises to near 50 percent of GNP in 1990, roughly its level in 1959. The view that the comparable decline in this ratio from 1959 to 1974 reduced interest rates is noticeably absent from contemporary or earlier studies. Also see footnote 3 above.

${ }^{13}$ The growth in the government budget deficit from 1980 to 1982 was cyclical in nature and would not have raised interest rates in any case. Investment demand is typically more strongly cyclical than budget deficits so that, even if the conventional view were correct, interest rates would not have risen due to cyclical deficit increases. Barro (1983) and Tatom (1984) detail the cyclical deficits since 1980.

${ }^{19}$ Since gross domestic investment equals national saving plus net foreign saving, the fiscal effects on saving musi be mirrored in similar changes in investment, other things equal.
} 
have little effect on interest lates or GNP, in this view, although they do change the mix of GNP and, depend ing on how they are financed, alter the mix of national saving.

In the absence of policy changes to reduce the shate of government expenditures in the nation's output, crowding out will remain a serious concern. The administration has proposed cutting the share of federal expenditures in GNP by 1990. This proposal focuses on reductions in government purchases." Such a pol icy would boost capital formation and economic growth by raising private and national saving rates. According to the classicat view, however, this may have little effect on interest fates. This view indicates that deficit reduction efforts that focus on maising taxes will have no shott-term impact on economic performance, but will instead simply reduce private saving by a comesponding amount.".

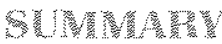

Populax analyses of recent and prospective U.S. govemment deficits suggest that deficits have raised output, prices and interest rates and crowded out private investment. The implication of this view is that futule budget cuts, in the short run, will retard the growth of aggregate demand but will lower interest rates, leading to a strengthening of private investment and longrun growth.

There are reasons to question the relevance and the

\footnotetext{
20 The link between deficits and the price level depends on whether increased deficits raise aggregate demand and on the extent to which deficits are accommodated by monetary growth. The classical view indicates that increased deficits do not raise aggregate dernand and, hence, cannot be inflationary. The second issue. however, whether deficits contribute to money stock growth and, hence, inflation, is not examined here. This link between the deficit and inflation is developed more fully in Hein (1981). See Hamburger and $Z$ wick (1981) for an altemative view.

${ }^{2}$ A detailed analysis of the unified budget proposals indicates that they focus on reductions in federal aid to state and local governments, agriculture and other purchases. These expenditures are principally either part of total government purchases directly, or they finance such purchases at the state and local government level. See Carlson (1985).

The earlier discussion does not distinguish between the type of taxes. Thus, the effects discussed are for average relationships. One of the most important qualifications that this raises concerns business tax changes that change investment incentives. The 1981 improvements in tax incentives for investment certainly lowered taxes and raised the deficit and may, at unchanged interest rates, have left national saving unchanged, as the classical view suggests. But the increased investment demand played a major role in boosting interest rates and thereby affected economic performance. Recent proposals to remove those incentives would reverse many of these effects on economic performance, even if the overall taxes and deficits are unchanged.
}

accuracy of the comventional view. It provides an inconsistent vew of recent ecomomic developments with inaccuracies ranging from the forecast of booming output, employment and inflation for 1981 and beyond, to the forecast of rising interest rates. In addition, the evidence here shows that the expected crowding out of investment has been offset by other factors, resulting in an investment boom since 1980.

The alternative hypotheses examined here indicate that fiscal policy actions are largely and directly offset by the private sector. Thus, tax changes are offset by adjustments to private saving, with no direct effect on national saving or investment. This classical view of fiscal policy also emphasizes that increased government purchases are directly offset by reduced private expenditures (especially investment).

According to the classical view, policy actions to reduce the deficit are not likely to affect interest rates and may not affect the invesment boom. For example, if defici reduction entails simply raising taxes, private saving will fall by a like amount and no additional investment will occur. To the extent that deficit reduction focuses on expenditures, however, investment will be strengthened, but without the inducement of lower interest rates.

The evidence from the recent experience suggests that the classical view is correct and indicates the importance of business tax cuts in raising domestic saving, investment and interest rates and reducing U.S. investment abroad. The evidence is not decisive as to which view more generally and accurately depicts the effects of fiscal policy on the economy, however. But both views indicate that domestic investment and economic growth are impeded by deficits arising from govemment expenditure growth, and that they are ulimately improved by restraint in such growth. Prom posals to deal with the deficit without raising taxes focus largely on reducing government nondefense pufchases. The successful implementation of these plans would ultimately raise private saving and investment, alter the composition of national output and promote economic growth.

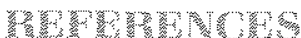

Aschaver, David Alan. "Fiscal Policy and Aggregate Demand," American Economic Review (March 1985), pp. 117-27.

Bailey, Martin J. National Income and the Price Level, 2nd ed. (McGraw-Hill, 1971).

Barro, Robert J. "Are Government Bonds Net Wealth?" Joumal of Political Economy (November/December 1974), pp. 1095-117. 
"On the Determation of the Public Debl," Journal of Poltical Economy (October 1979), po. $940-71$

"Outout Enfocis of Government Purchases," Jounal of Political Economy (December 1981). pp. $1096-121$

"The Behavior of U.S. Deficits," University of Chicago (March 1983). unoublished.

Bunner, Kart. "Fiscal Polcy in Macro Theory: A Survey and Evaluation," in The Monetary vs. Fiscal Policy Debate, conference pro ceedings, Ootober 12-13. 1984, Federal Fesarve Bank of S. Lous, forthcoming.

Carson, Kein M. "Contromg Federal Outays; Trends and Proposals," this Revew (June buly 1985), pp. 5-11.

............. "The Mrx of Monetary and Fiscal Policies: Conventional Wiscom ys, Empirical Feanies, "this Revew (October 1982), pp. $7-2 t$

Carson, Keih M. and Roger W. Spencer. "Crowding Out and its Critics" his Revew (December 1975), p0. 2-17.

Congressional Budge ofice. The Fonomic and Budget Qubok Fiscal Years $1980-90,1985$ Annual Pepot, Congress of the United States (GPO. February 1985 ).

Council of Economic Advisers. Economic Pepont of the President (GPO, Felpruary 1985).

Davd, Paul A., and John , Scadding. "Prvats Savings: Unrarationalty, Aggregation, and Denison's Law', Loumd of Poltical Economy (Varchiapril 1974), po. 225-49.

Denison, Edward I". "A Note on Private Saving:" The Review of Economics and Statistics (Avgust 1958), pp. 261-67.

Dolan, Edwin G. Basic Economics, 3 rd ed. (CBs College Publish ing. The Dryden Press, 1983 ).

Evars, Paul. "Do Large Deficits Produce High Interest Rates?" Amenican Economic Peview (March $\$ 985$ ), pp. 68-87.

Foldstein, Marin. "Govemment Delicis and Aggregate Demand," Joumal of Monetary Economics (January 1982), pp. 1-20.

Feldstein, Martin and Oto Eckstein. "The Fundamentel Dekeminants of the interest Rate." Review of Economics and Statistios (November 1970 ), pp. 363-75.
Friedman, Milon. A Theory of the Consumption Function (Princeton University Pross, 1957).

Hater, R. W. "The Pole of Fiscal Policy in the St. Louis Equation," this Review (January 1982), po. $17-22$.

Hall, Rober E. "Labor Supply and Aggregate Fluctuations." Gamegie-Pophester Conference Senes on Publo Policy ISpring $1980\}$, op. $7-33$.

Hamburger, Michael J., and Buton Zwick "Deficits, Money and Inflation:" Joumal of Monerary Economics (January 1981), pp. $141-50$

Hein, Scott $E$.Oeficts and Inlation," this Pevew (March 1981 ), po. $3-10$

Hickman, Bert G. "Investmen Demand he Sixties," Reprin No. 120, The Brookings institution, 1966.

Kochin. Levis. "Are Future Tayes Discouned by Consumers? A Comment," bumal ot Money, Credi and Banking (August 1974 ), pp. $385,-94$

Fomend, Foger C. "Govemment Debt, Govermment Spending, and Private Sector Behavior," American Economic Review (December 1983 ), pp. $994-1010$.

McConnel. Campoel R. Economics. 9h ed. (MoGraw Mtit, 1984).

Ofice of Management and Budget. Budget of the United States Govenment 1986 (GPO, 1985 ).

Plosser, Chartes 1. "Govemment Finamcing Decisions and Assex Returns:" Joumal of Monetany Economics (May 1982), pp. 325-52.

Samulson, Paul E., and Wiliam D. Northaus. Economics, 12 thed. (MoGraw Hill, 985 ).

Sargent, Thomas J. "The Fundamental Deteminants of the Interest Pate: A Comment," Review of Economics and Statistics (August 1973), op. $391-93$

Tanner, J. Emest. "An Empirical Imestigation of Tax Discountingr" Joumal of Money, Credit and Banking (May 1979), pp. 214-18.

Tatom, John A. "A Perspective on the Federal Deficil Problem," this Fevien (June/ Suly 1984), pp. 5-17.

U.S. Department of the Treasury. The Effects of Deficits on Prices of Finencial Assels: Theory and Evidence (GPO, March 1984). 